\title{
Preschool English Education in the Spanish Curriculum. Analysis of the Region of Murcia
}

\author{
ZHOU PING \\ Hunan Normal University (China) \\ Gregorio Vicente Nicolás and Yvette Coyle \\ University of Murcia (Spain)
}

Received: 10 October 2011 / Accepted: 10 March 2012

ISNN:1697-7467

\begin{abstract}
This article analyses the current situation of preschool English Foreign Language (EFL) education in the Region of Murcia from three critical perspectives: teachers, teaching approaches and textbooks. A total sample of 106 preschools throughout the region completed research questionnaires. The results of the data analysis show that while preschool English teaching in the Region is now well established, there are still certain areas which should be highlighted for improvement. Specific issues in need of further attention include the strengthening of teacher training for this age range and the extensive use of textbooks written by British rather than local publishers.

Keywords: preschool education; curriculum; English teachers; textbooks.

El inglés en la Educación Infantil en España. Un análisis de la región de Murcia

RESUMEN: El objetivo de este artículo es conocer la situación actual de la enseñanza del inglés en Educación Infantil en la Región de Murcia desde tres perspectivas: el profesorado, las prácticas docentes y los libros de texto. Para la recogida de datos se ha elaborado un cuestionario y la muestra está formada por 106 centros de Educación Infantil de la Región. Los resultados revelan que la enseñanza del inglés en los centros de Educación Infantil está sistematizada y regulada en su conjunto. Así mismo, existen algunos aspectos que son susceptibles de mejora como son la formación del profesorado, la orientación de las clases de inglés en Educación Infantil similar a la etapa de Primaria, o la escasez de editoriales nacionales debido a la adaptación de textos de editoriales extranjeras.

Palabras clave: educación infantil, currículo, profesorado de inglés, libros de texto.
\end{abstract}

\section{INTRODUCTION}

With the development of the multi-polarization of worldwide politics as well as the globalization and unification of worldwide economics, communication between different districts and nations is becoming more and more frequent. As the second most frequently used language and the first commercial language in the world, English plays an important role on the international stage. From late 1980s and early 1990s, the teaching of English a foreign language has become part of the compulsory curriculum of early childhood education 
in many countries leading to the subsequent development of different teaching approaches. Unlike the situation in China and some European countries, preschool EFL teaching has been part of the statutory curriculum in Spain since 2004 (Ministerio de Educación, 2004: 5042-5048). The introduction of EFL at such an early stage of children's education is not so common in other parts of the world and as such aroused our research interest. Specifically, our concern is to learn more about preschool English education in Spain; the advantages and disadvantages of an early start, together with the possible inspiration of the Spanish context for the curriculum of other school districts.

Curricular information on preschool EFL education in Spain dates back to the 1990s. In the Real Decreto ${ }^{1}$ (from now on RD) published on September 6th, 1991, which established the curriculum for preschool education, foreign language teaching was not initially included. Five years later, however, the Orden ${ }^{2}$ of April 29th 1996 authorized the introduction of English teaching experimentally in the second cycle of preschool education (Ministerio de Educación y Ciencia, 2007: 1019). The RD of January 23rd, 2004, specifically highlighted the importance of an early start to foreign language learning in schools, and emphasized the importance of developing children's oral communication skills as well as the integration of content from other curricular areas with foreign language learning in the third year of preschool education. It further provided detailed learning objectives and evaluation criteria for foreign language learning (Ministerio de Educación, 2004: 5042-5048). The perceived success of EFL teaching in schools meant that two years later, English would be extended to the second year of preschool education by the RD of December 29th, 2006 (Ministerio de Educación y Ciencia, 2006: 480-481) and Order ECI/3960 of December19, 2007 (Ministerio de Educación y Ciencia, 2007: 1017), which clearly indicated the importance of using a foreign language in daily routines and classroom situations.

Within the Region of Murcia, EFL was being taught experimentally from as early as the second cycle of Preschool Education and the first cycle of Primary Education in some schools from 1996-1997. However, it was not until 2005 that English was officially established as part of the preschool curriculum (Consejería de Educación y Cultura de la Región de Murcia, 2005: 13685). From 2005 onwards, the teaching of English was gradually introduced within preschool education, initially to 5 year old children in Year three, and then successively to 4 year olds in Year two in 2006 and finally to Year one three year olds in 2007 (Ministerio de Educación y Cultura, 2005: 13685). In the Decreto ${ }^{3}$ published on August 1st, 2008 by which the preschool curriculum for the Region of Murcia was established, emphasis was placed on the importance of developing children's communicative skills in different languages. The methodological recommendations provided for teachers suggested that they should focus on developing children's positive attitudes towards the foreign language and culture together with their acquisition of oral comprehension, using the target language as the basis for communication, in activities that matched children's different styles and rates of learning (Decreto 254, 2008: 24961-24964).

\footnotetext{
${ }^{1}$ Real Decreto is an official government Act that has the force of law.

${ }^{2}$ Orden is a legal mandate commissioned by the government.

${ }^{3}$ Decreto is a legal norm issued by administrative authorities without having the category of a law.
} 


\section{2. МетноD}

\subsection{Participants}

In the Spanish context, preschool education includes children's education from birth to six years of age. This stage consists of two cycles: the first cycle comprises birth to age three, while the second cycle includes education from 3 years to 6 years of age (Ministerio de Educación, 2011). For the purposes of this study, we focused on the second cycle of preschool education using a random sampling methodology. The participants in the study were preschool teachers from a total of 106 preschools or Colegios de Educación Infantil $y$ Primaria (CEIP from now on) in the Region of Murcia.

\subsection{Research Instrument}

Data for the study was collected using a written questionnaire consisting of three main sections: i) respondent's personal information, ii) the teaching of EFL in preschool, iii) the use of preschool English textbooks. The items included in Part 1 of the questionnaire are as follows:

- Sex

- Age

- Length of time teaching

- Educational background

- Major during the teacher's training

In the second part of the questionnaire, we designed 5 questions which aimed to identify the practices and personal opinions of EFL teachers in the Region. The questions tapped into the following aspects:

- Frequency of English classes in the school

- Length of English lessons

- Number of teachers per school and age groups they teach

- Teachers' personal opinions as regards the right moment to introduce EFL

- Frequency of writing tasks

As regards the use of preschool EFL textbooks in the Region of Murcia, 5 questions were included to inquire about the main textbooks used in English classes during the school year 2010-2011, the use of other additional texts for lesson planning, and the frequency with which teachers used them. These items included:

- Use of an EFL textbook

- Frequency with which teachers use textbooks

- Which textbooks are used when preparing lessons

- Who decides which textbooks to use

- Criteria used for choosing textbooks

\subsection{Procedure}

The questionnaire used in this study was originally tested in a pilot study carried out in nine schools within the region, enabling us to revise and validate the items before embarking 
on the major research project. A link to an on-line version of the questionnaire was sent to 382 schools throughout the region. In all, we received 108 responses. Two questionnaires were discarded as they were repetitions by teachers from the same schools, leaving a total of 106 effective questionnaires.

\section{Data Analysis}

The online questionnaire data were analyzed using the descriptive statistics software package SPSS 15.0. Frequency counts were made of the teachers' responses in an attempt to establish a professional profile of preschool English teachers together with the most salient characteristics of their teaching approaches.

Chi-Square tests were also carried out on the data taking into account the sex, age, teaching age, educational background, the major of the preschool English teachers and the frequency with which they claimed to use textbooks. The results of the questionnaire data are reported below.

\section{RESUlts}

\subsection{Preschool English teachers in the Region of Murcia}

The first groups of questions focused on personal information in relation to the preschool teachers. According to the information gathered from the questionnaires, a few of the participants were teaching English in preschool as early as 1980 (Table 1). Others began to teach English from the early 1990s, while the majority began from 2000 onwards. Nowadays, nearly all schools teach English to preschool children in the Region of Murcia (3-6 years).

Table 1. The beginnings of EFL in preschools in the Region of Murcia.

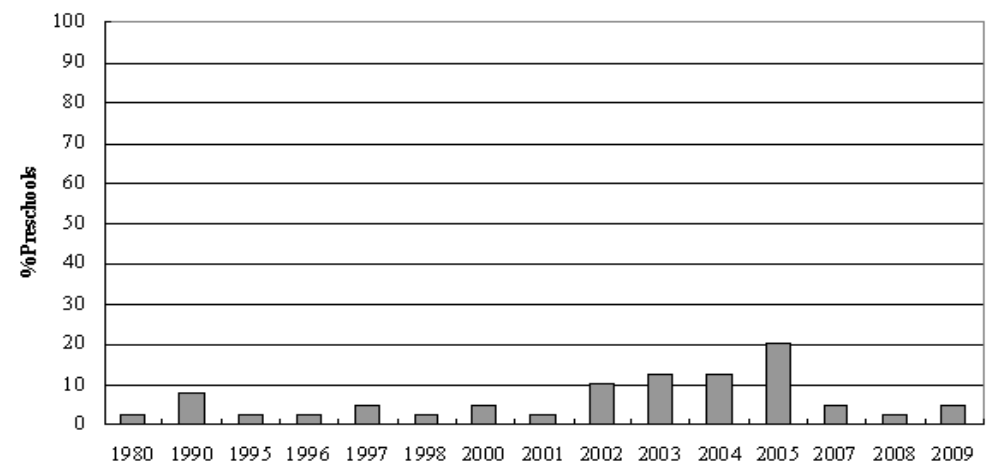


As can be seen in Table 2, the percentage of male preschool English teachers in the region is approximately $20 \%$ as compared to $79 \%$ of female teachers. Wang Chengde, (2007: 208) has argued that the differences in ways of thinking and behaving of male and female teachers, can influence children's language development as well as their emotions, behavior and thoughts, especially in preschool. Liu Ping, (2006: 22-25) goes further by suggesting that a lack of balance with an excess of female teachers but too few male teachers in preschools is not beneficial for children. However, in most countries, perhaps because of stereotyped roles of men and women, the ratio of women teachers in preschool education is much greater than that of men (Liu Ping, 2006: 20-21). Although in Murcia the ratio of male preschool English teachers is not as low by comparison with other districts and nations, it is still not particularly high. It would seem, then, that there is still work to be done by the local educational authorities in attracting male teachers to the profession and improving the position and benefits of preschool English teachers.

Table 2. The sex of the preschool English teachers in the Region of Murcia.

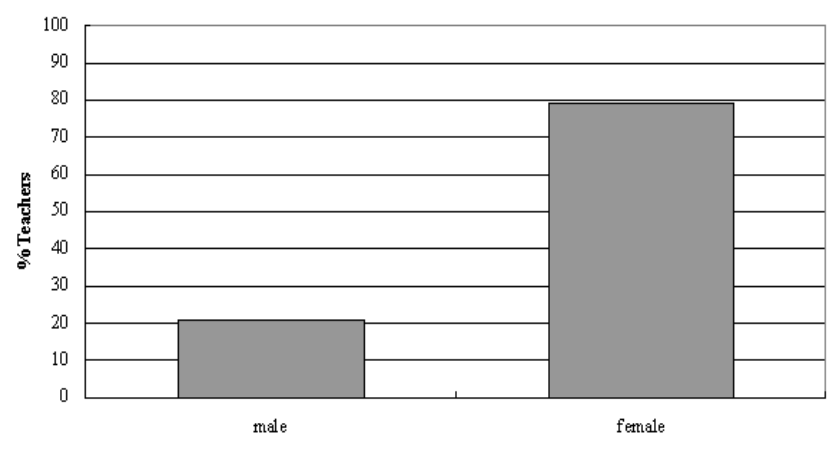

It is widely assumed that older and more experienced teachers are more suited for working with young children, and that teaching preschool children is an easy task which does not require a great deal of specialist knowledge. But in fact, teaching young children well needs a solid theoretical knowledge base and specific practical skills. This is especially true of the English language requirement for preschool teachers which some older teachers lack. Based on the questionnaire results (Table 3), we can see that the English preschool teachers in the region are a relatively young population, since the majority, more than $70 \%$, are aged between 20 and 40 years old. It is interesting to highlight that less than $5 \%$ of preschool English teachers are over 50 years old. 
Table 3. The age of preschool English teachers in the Region of Murcia.

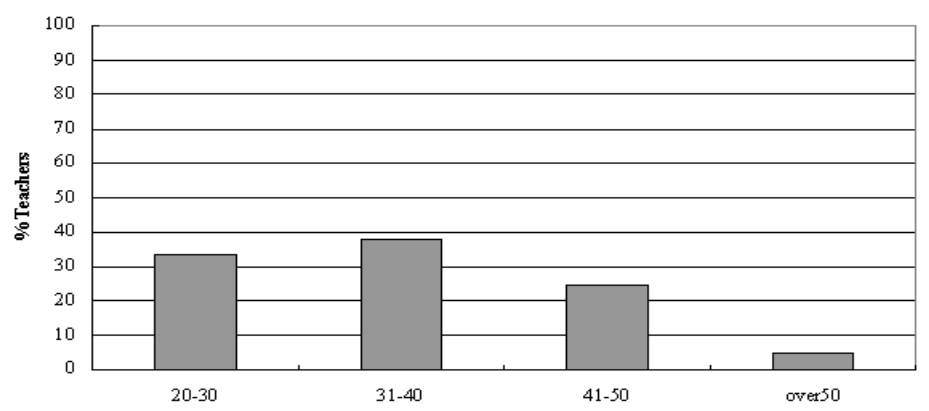

Table 3: The age of preschool English teachers in the Region of Murcia

The questionnaire further probed the experience of preschool teachers in terms of the length of time they had been teaching. In this respect, nearly $60 \%$ of the teachers had been teaching English between 1-5 years and about one third between 5-10 years (Table 4). Although preschool EFL teaching is a still a relatively young endeavor, the number of preschool English teachers in the Region of Murcia seems to have increased rapidly within the past few years since the statutory introduction of English within the early years curriculum in 2008.

Table 4. The teaching experience of preschool English teachers in the Region of Murcia.

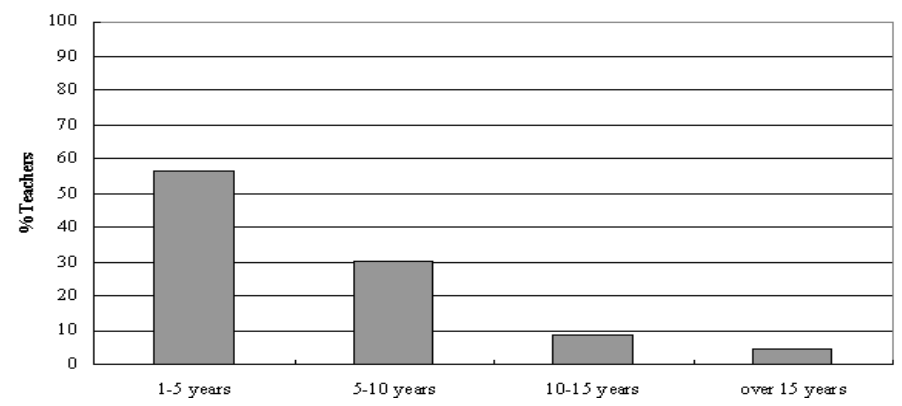

Table 5 shows the educational backgrounds of the preschool English teachers who responded to the research questionnaire. These correspond largely to three main types of qualifications: i) the Teaching Diploma or Diplomatura which is a three year university course, ii) a Bachiller's Degree or Licenciatura a 5 year specialist degree course, and the Training Course or Curso de Habilitación for qualified teachers who wish to transfer to another subject field and which can last from several months to one year. The majority of the teachers $(81 \%)$ who responded to the on line questionnaire hold a Diplomatura, $13 \%$ 
have a Licenciatura and a much smaller number have transferred to English teaching via the Curso de habilitación (5\%) Only $0.9 \%$, as seen in the 'Others' section, are teachers who hold a doctorate (Table 5).

Table 5. The educational background of preschool English teachers in the Region of Murcia.

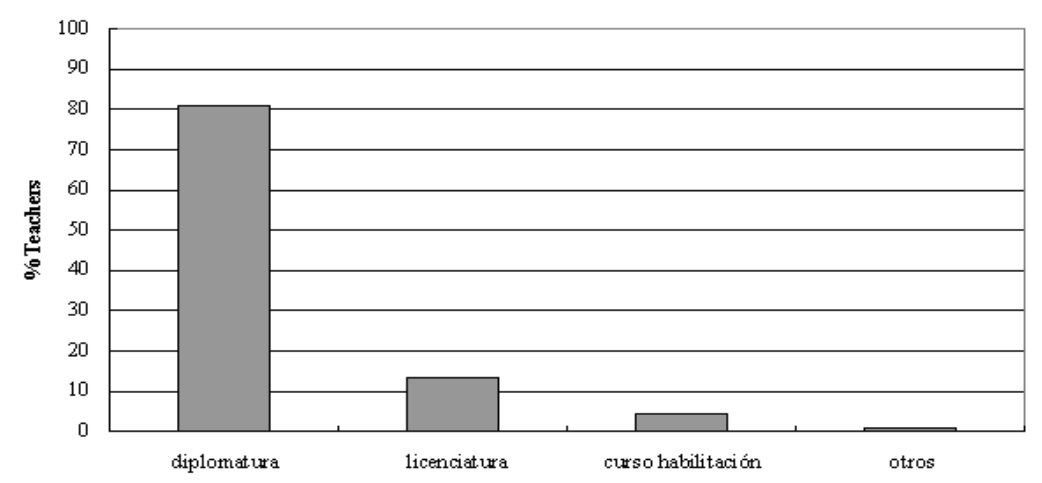

Based on the questionnaire data (Table 6), over $80 \%$ of preschool English teachers in the Region of Murcia originally majored in English Language Teaching at primary level (Maestro en Lenguas Extranjeras: Inglés) and so lack specific training in the knowledge and skills required to teach smaller children. Only $4 \%$ of the preschool English teachers in the region have Preschool Education studies (Maestro en Educación Infantil), and unlike the primary EFL teachers, are likely to require thorough training to develop their English language skills. A further 5\% of the preschool English teachers are teachers who have transferred to English after taking an intensive specialist training course (Curso de Habilitación). The category Others $(8 \%)$ includes teachers who have different degrees. This combination of educational backgrounds shows that in-service training for these teachers in the Region of Murcia is critical at this moment in time.

Table 6. The initial major of the preschool teachers in the Region of Murcia.

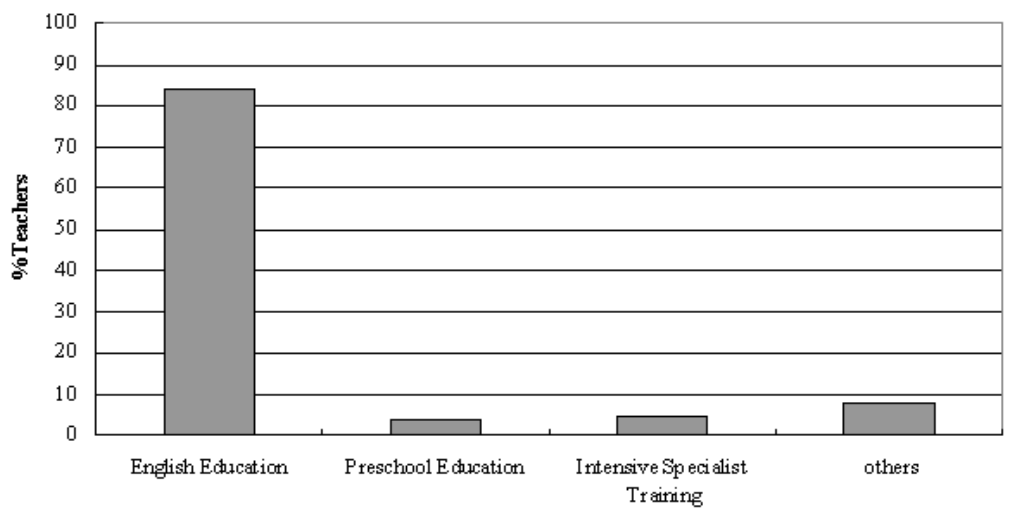




\subsection{EFL teaching practices in preschools}

The second group of research questions aimed to identify how the teaching of English is translated into specific practices within schools. The questionnaire categorizes the frequency with which English is taught in schools into 8 levels: $0=$ never, $1=$ seldom, $2=$ once a week, $3=$ twice a week, $4=$ once a day, $5=$ bilingual, $6=$ immersion, $7=$ others. As can be seen in Table 7, the most popular mode of lesson frequency is twice a week. For the 4 and 5 year old age range, over $80 \%$ of the preschools teach English to the children twice a week. For the 3 years old group, nearly $70 \%$ of the preschools teach English to the children twice a week. About $20 \%$ of schools teach English once a week and $0.9 \%$ of the preschools never teach English to the children. The findings also show that none of the schools engage in bilingual English teaching and only $0.9 \%$ of them use an immersion approach.

Table 7. The frequency of the preschool English classes in the Region of Murcia.

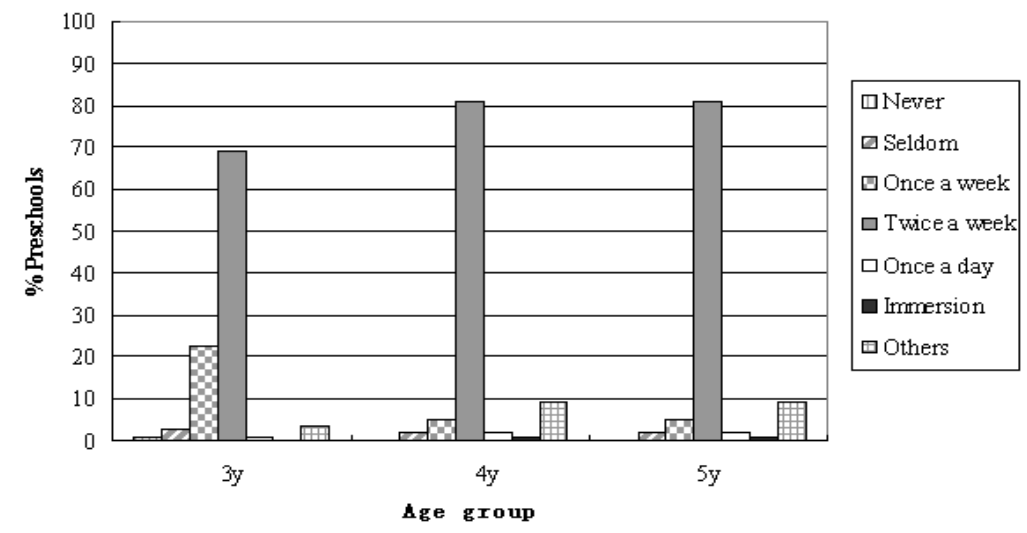

The duration of the English classes has also been coded into 8 levels, $0=$ never, $1=20$ minutes, $2=30$ minutes, $3=40$ minutes, $4=45$ minutes, $5=50$ minutes, $6=1$ hour, $7=$ over 1 hours, $8=$ others. Based on the research data (Table 8 ), for the 4 and 5 year old groups, the majority of classes last for 45 minutes, while for the 3 year old, classes generally last 30 minutes. In the case of just over $10 \%$ of the teachers who responded to the questionnaire, English classes were reported as lasting more than one hour: This was even more frequent among 3 year olds, where the percentage increased to $20 \%$. This finding is surprising given the young age of the pupils. However, when teachers were questioned about this after the research, many confirmed that 3 year old groups generally needed more specific attention and care, so the organization and delivery of activities made longer sessions necessary. 
Table 8. The duration of preschool English classes in the Region of Murcia.

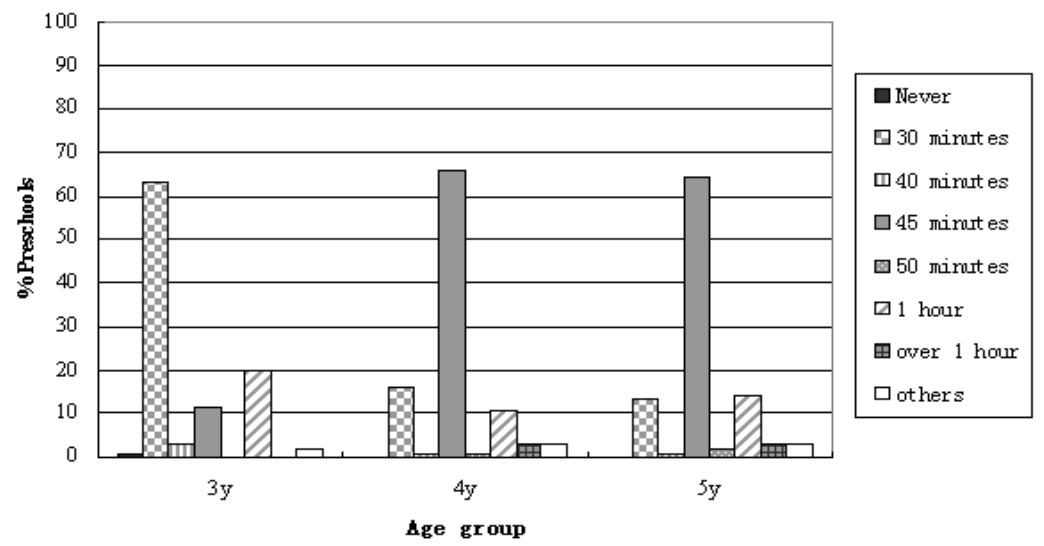

As one of the four main components of the curriculum: learners, teachers, instructional materials and the context (Schwab, 1969: 287), preschool English teachers play an important role in the educational process within the whole school. Their place in the school is an important factor in the delivery of the curriculum and undoubtedly influences the quality and efficiency of English education. Unlike other countries, from the 1970s and especially during the 1990s, preschools in Spain gradually became integrated with main primary schools and called Colegios de Educación Infantil y Primaria (CEIP) as a whole. In this sense, the role of English teachers in the CEIP is a little different from preschools in other countries. In China, for example, preschools and primary schools are totally independent. Teachers work in either one or the other, but not both and generally follow different teaching methods and timetables according to the age of the children. In Spain, we find 3 main teaching situations: M1 = where there is only one English teacher for the whole age range in a school, including therefore preschool and primary aged children, M2= teachers who are specifically responsible for preschool only since other colleagues within the school teach EFL at primary level and M3= different teachers share responsibility for EFL in pre and primary schools. The latter refers to situations in which one teacher might teach the 3 and 4 year olds, while another teaches the 5 year old preschoolers as well as other classes at primary level.

Among the preschools in the study (Table 9), about 55\% have a professional English teacher who teaches the whole age range within the school. About $40 \%$ of the respondents selected the M3 option, indicating that many schools employ two or three English teachers who share the teaching throughout the preschool and primary levels. Often one teacher takes the upper age range and the other takes the younger children, occasionally they choose the level randomly. 
Table 9. Preschool English teachers' location in the Region of Murcia.

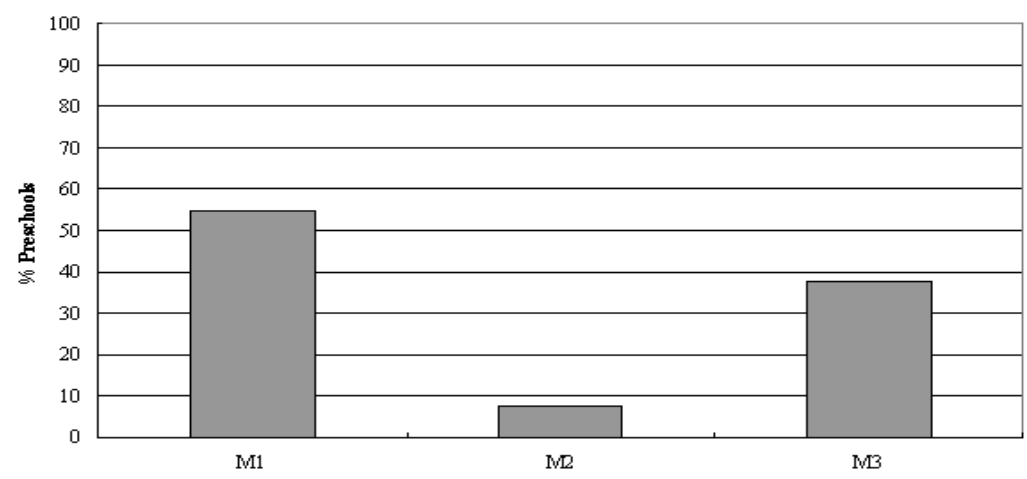

The age at which children should begin learning a foreign language has been a major research topic and a controversial issue for some time now. Our research examines this question from the viewpoints of the preschool English teachers. The results show (Table 10) that more than three fourths of the preschool English teachers in the study think that children should begin to learn English before the age of 3. It is striking that few teachers feel that 'the older the better' is preferable, as recent research on the age factor has reported (Muñoz, 2006).

Table 10. Teachers' opinions on what age children should begin learning English.

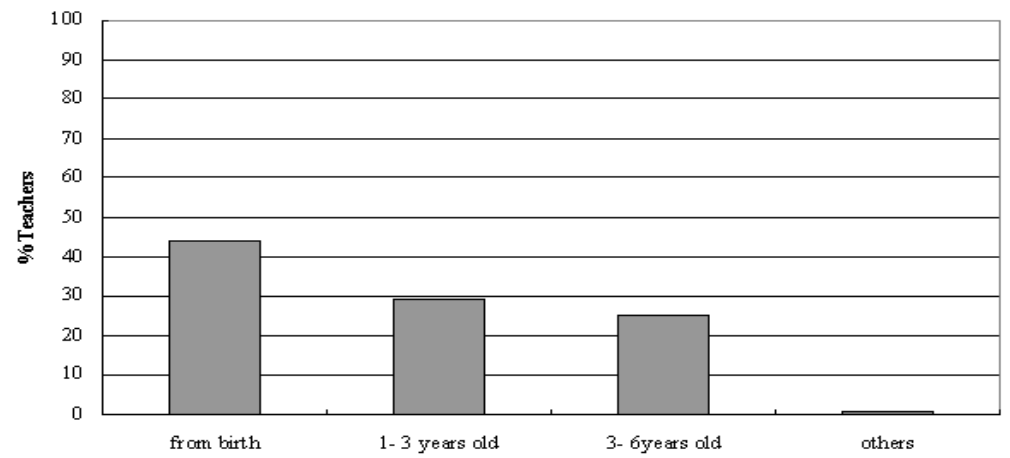

Learning to write in the first language plays a special role in the theory and practice of preschool education. However, when it comes to learning a foreign language, oral skills are emphasized more. This is reflected in the preschool Curriculum of 2008 which approaches written language initially through the development of children's receptive skills by having them identify and create visual associations with spoken messages or texts which are read aloud. The question of EFL writing then is one which is not officially contemplated in preschool. The results of the questionnaire data generally confirm that this is the case, 
although preschool English teachers do vary slightly in their attitudes towards the teaching of writing. In general, writing does not form part of the regular practice in preschool EFL classes. Approximately $60 \%$ of teachers never teach writing to the children (Table 11), and no more than $7 \%$ admit to teaching writing often. This shows that for the most part, preschool EFL teachers work within curricular recommendations.

Table 11. Presence of writing in the preschool English Class in the Region of Murcia.

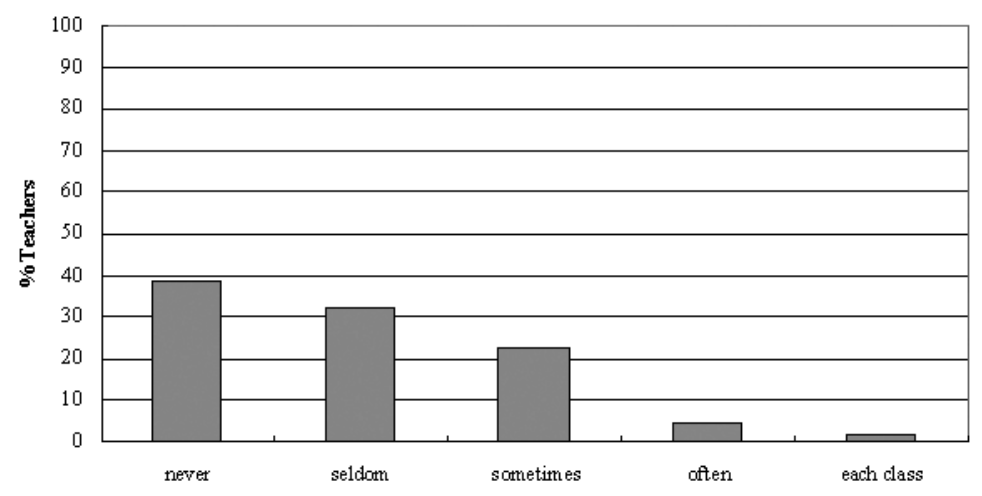

\subsection{Preschool English textbooks in the Region of Murcia}

The third group of questionnaire items aimed to gather information on the use of EFL textbooks among preschool teachers in the region. Arnold and Rixon (2008: 48) have classified young learners' English materials into two main groups: those which emphasize grammar in preparation for special tests and those which are activity-based and pay less attention to the linguistic content. The latter are more child-friendly and meaning-oriented. Preschool English textbooks in Spain generally belong to the second group in that they are activitybased. Materials for schools include the pupils' books and the teacher's guide. The teachers' guide includes guidelines for carrying out activities designed according to the children's age and curriculum objectives, while the pupils' books include one or two principal activities per session. One of the goals in this study was to discover just how many preschools use English text books with the children.

In the questionnaire, the frequency with which textbooks are used by preschool teachers was divided into 5 levels: $0=$ never, $1=$ seldom, $2=$ sometimes, $3=$ often, $4=$ each class. According to the results (Table 12), about one third of the preschool English teachers never or seldom use English textbooks in their classes whereas nearly half of the teachers often use the textbooks in the preschool English class. Chi-Square tests were carried out on the data taking into account the sex, age, teaching age, educational background, the major of the preschool English teachers and the frequency with which they claimed to use textbooks. The results showed that none these factors have any obvious correlation with textbook use. The combined percentages of the teachers' responses do reveal, however, that over $65 \%$ of teachers use published materials in their classrooms. 
Table 12. Use of English textbooks in preschools in the Region of Murcia.

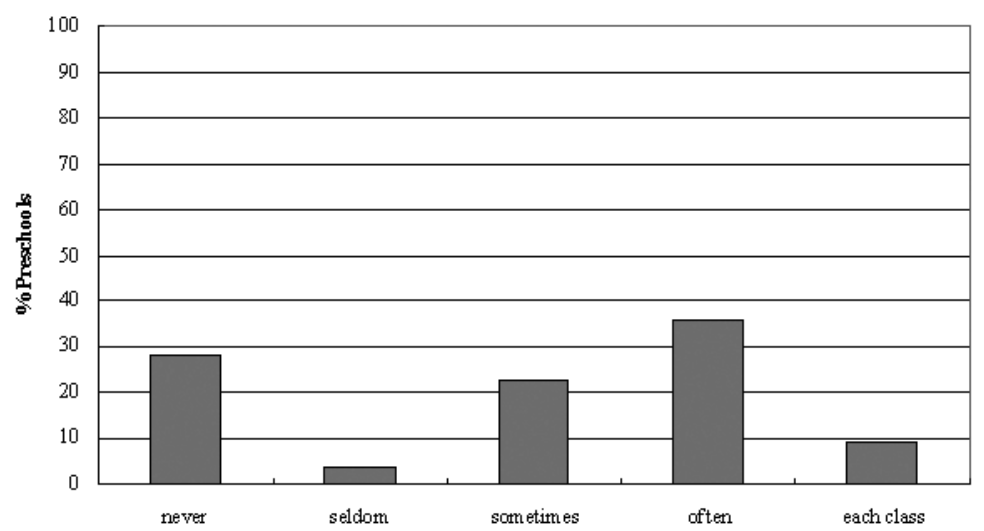

There is a wide variety of textbooks used in schools throughout the region. Based on the research data (Table 13), the five most popular publishing houses were categorized as follows:
- P1: Macmillan
- P2: Oxford
- P3: Richmond/Santillana
- P4: Longman/ Pearson
- P5: Algaida

Table 13. Popular publishing houses in the Region of Murcia divided by age group.

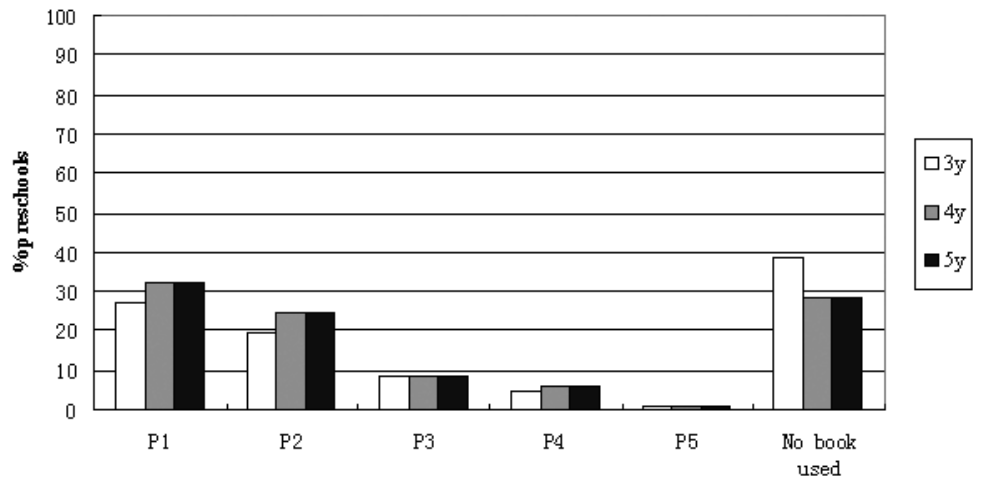

In response to the question on their use of additional textbooks (Table 14), no more than $30 \%$ of the preschool English teachers confirmed their use of another textbook to prepare their classes, and no more than $10 \%$ use two additional textbooks. 
Table 14. Use of additional textbooks to prepare preschool English classes.

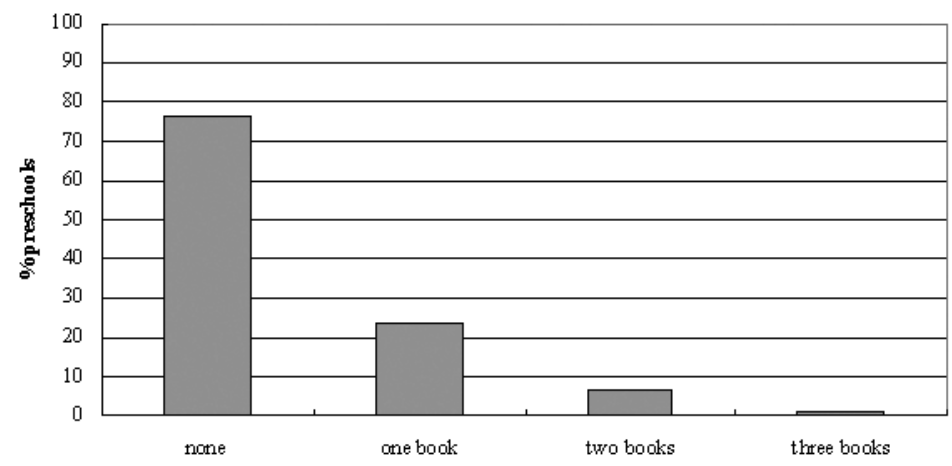

The decision as to which published materials to use for teaching English varies according to schools (Table 15). In some schools, it is the head teacher who decides which textbook to use; in others a group of English teachers decide; sometimes the preschool English teacher is responsible for choosing the materials. Occasionally, the English coordinator within a school or a group of university teachers decides which textbook to use. The most common situation is that the decision is made based on the deliberations of a group of teachers, which reflects a democratic decision-making process within schools as well as the collective intelligence of a team of teachers.

Table 15. Collectives responsible for choosing the textbook.

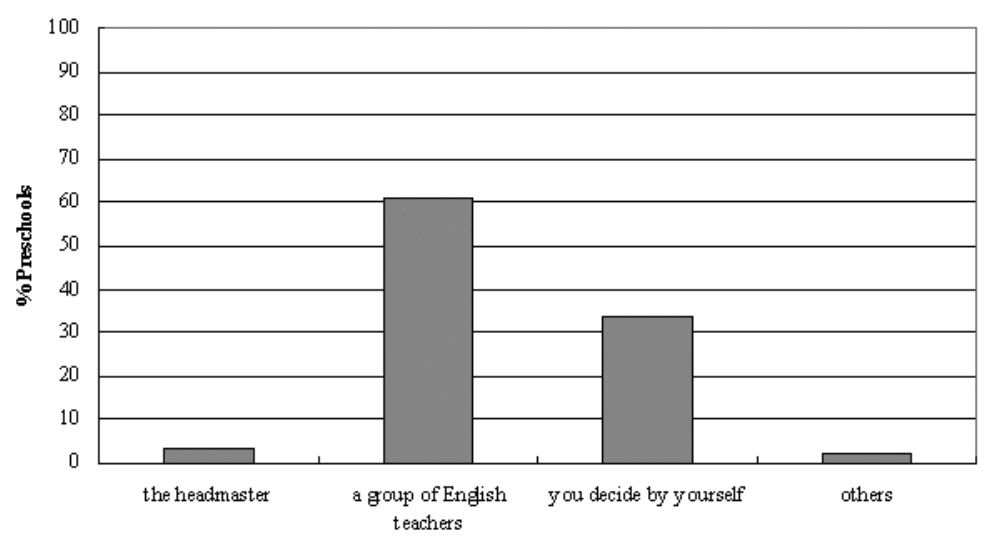

Among the factors which influence the decision to choose a specific text book or not (Table 16) teachers mentioned issues such as the content (79\%), the provision of supplementary resources and materials (64\%) or the underlying curricular approach (51\%). Surprisingly, more than half the teachers asked (56\%) considered the physical appearance of the book important. Factors which were not considered important included the publishing house itself $(84 \%)$, the author of the textbook $(84 \%)$ and the title $(96 \%)$. 
Table 16. Factors which influence the choice of textbooks.

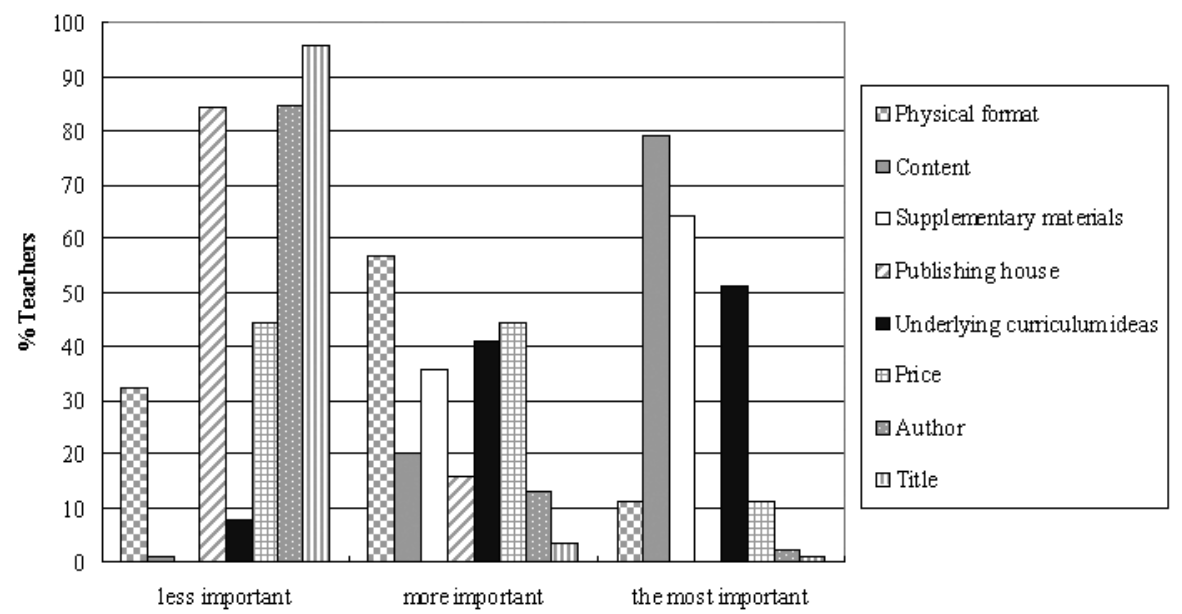

As regards the content of the preschool English textbooks (Table 17), the factors teachers reported paying most attention to included the activity types (87\%), the topics of the units $(83 \%)$, the types of stories included in the text book $(65 \%)$ or the organization of the content $(59 \%)$

Table 17. Factors which influence the choice of textbook content.

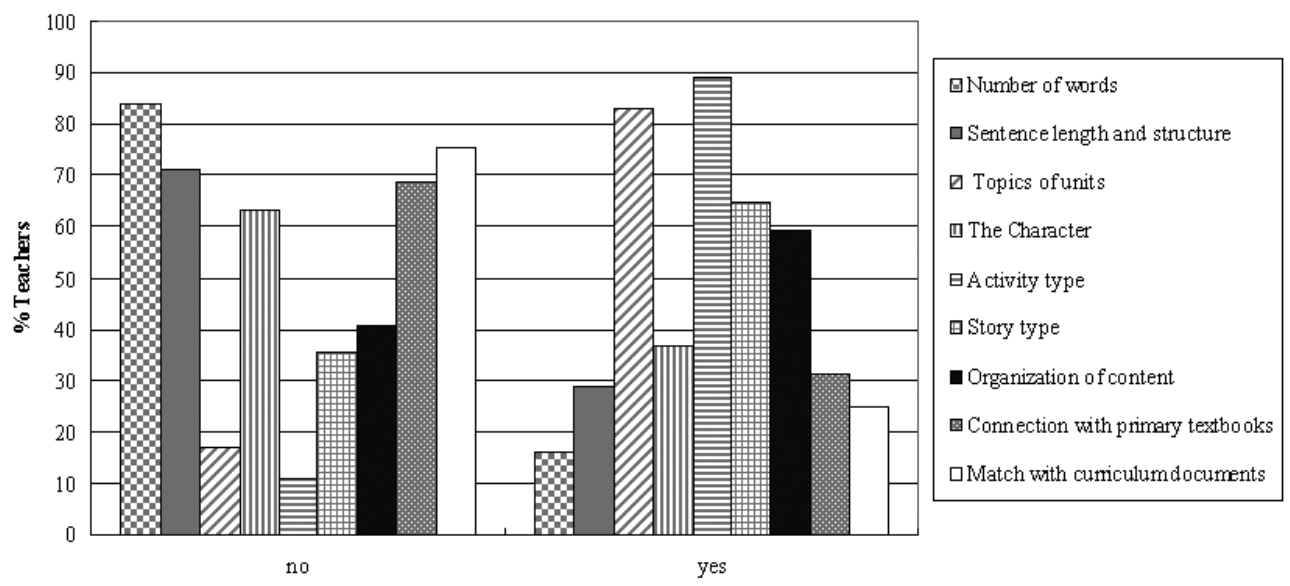




\section{Conclusion and Discussion}

The results of the analysis of questionnaire data indicate that after an experimental phase and four years of statutory curriculum, preschool English education in the Region of Murcia is firmly established, with a body of relatively young preschool English teachers and a variety of published materials to choose from for preparing lessons. These general findings can be summarized as follows:

The majority of the teachers who teach English in preschool are young: approximately $70 \%$ are no more than 40 years old and hold teacher training qualifications from a 3-year professional training course. Most of the teachers hold a Diploma in Primary Level English Language Teaching and have a strong knowledge of the foreign language but lack the methodological skills for teaching very young learners. Importantly, the vast majority believe that teaching English to preschool children is possible and accessible. Most of the preschools in the Region of Murcia have established timetables for teaching English. The most popular timetable is two 30 minute sessions twice a week for the 3-year-old group, which increases to 45 minutes for 4 and 5 year old children. English is taught as an independent subject rather than bilingually or in an immersion environment. The preschool English teachers in the Region of Murcia are free to choose the textbooks they prefer, with most decisions taken collectively by groups of colleagues within a school based on criteria which includes content matter, activity types and the degree of attractiveness. Verbal skills are emphasized and the teaching of writing is rare.

However, the research data have also indicated a number of areas in which improvements could be made. While all teachers play an important role in their pupils' education, preschool English teachers particularly are crucial to the development of their young learners' communicative competence in their second language. The requirements then for these teachers are specific. Eligible preschool English teachers should not only have sufficient professional knowledge and competence in English, but should also be fully grounded in the theory and practice of preschool education, especially the characteristics of child development. In this sense, preschool English teachers who have graduated from Primary Level English Language Teaching often lack specialist knowledge of preschool children and teaching, while teachers, whose studies are in Preschool Education, generally have poor linguistic competence. A combination of specialist methodological knowledge and language skills would seem to be the ideal solution. Training for those teachers who study Preschool Education should include a strong language component, while the Primary level ELT degree should include methodological strategies aimed at very young children, at least while primary English teachers are expected to teach EFL at preschool level. It is apparent that one of the challenges to be faced in the future is the strengthening of initial teacher training in higher education, as well as in-service training for employed teachers, in order to ensure more competent and comprehensively trained preschool English teachers.

The age at which English should be taught is still a controversial issue. Although the teachers questioned in this research confirmed their belief in teaching English to very young learners, there are still opposing opinions as to whether English should be taught to preschool children. Those who support the view the earlier, the better base their views on the Critical Period Hypothesis of children's language development and argue that learners who miss the opportunity to acquire a second 
language early in life generally spend longer learning it as adults and fail to reach native-like competence. Experts in psychology and linguistics such as Chomsky, Lenneberg, Chambers, Stromswold, etc., advocate this view. Researchers who maintain the opposite opinion, for example Muñoz (2006) affirm that the language learning process in young children is slow and difficult and no more advantageous than if they had started to learn languages at a later stage.

Given these differences, and considering the interest expressed by the participants in this research, it is our belief that, the local educational authorities in the region should consider recruiting a group of experts in relative research fields, as well as preschool English teachers and parents, to take on a wide scale investigation on the implementation of foreign language teaching with very young children. Doing so would enable them to make a comprehensive assessment of the appropriateness and effectiveness of preschool English education. Listening to teachers' opinions on issues such as when and how to teach English, the timetabling and length of language lessons or the adequacy and usefulness of available materials, could help to improve educational policy and the long term development of preschool English education.

As stated above, in preschool English education, the text book has become one of the most important curricular resources and pedagogical guides for teachers, especially for the younger preschool English teachers who lack the experience or confidence to design activities themselves. In this sense, the choice of a suitable textbook is essential for the successful delivery of the curriculum. The results of the current research has revealed that most of the English textbooks used in schools have either been published by British companies such as Macmillan, Oxford, Richmond and Longman, or have been adapted by Spanish publisher's such as Santillana or Pearson. Other textbooks compiled by some of the more well known national publisher's such as Anaya, Edebé, SM, Everest or Alhambra are not as popular. This may be due to the quality of the textbook itself or only an orientation of cultural values which lean towards English as the mother tongue. Whether teachers should continue to rely on prescriptive textbooks to interpret the curriculum or whether indeed they should dispose of text books altogether and plan and design their own activities with specific learners in mind, is another issue that merits further discussion and research. Perhaps, one solution would be for teachers to have access to published resources and banks of different activity types which could be used flexibly and adapted to specific preschool educational contexts.

\section{REFERENCES}

Arnold, W. \& Rixon, S. (2008). Materials for Teaching English to Young learners, in B. Tomlinson (ed.), English Language Learning Materials: A Critical Review. London: Continuum, 48.

Comunidad Autónoma de la Región de Murcia. Decreto 254/2008, August 1, to establish the curriculum of the second cycle of preschool education at the autonomy community of Region of Murcia. Official Bulletin of Region of Murcia. No. 182 , 06/08/2008. 2496124964, 24971, 24964.

Liu, P. (2006). On the Gender Structure Problems and Countermeasures of the Infant Teachers in the Kindergarten. Changsha: Hunan Normal University. 
Ministerio de Educación y Cultura. Orden of May 20, 2005, to establish and implant English as a foreign language at the level of preschool education in all the educational centers which are authorized such education. Official Bulletin of Region of Murcia. No.129, 07/06/2005. 13685.

Ministerio de Educación y Ciencia. Orden ECI/3960/2007, December 19, to establish the curriculum and regulate the management of preschool education. Official Bulletin of the State. No.5, 05/01/2008. 1019, 1017.

Ministerio de Educación. Real Decreto 114/2004, January 23, to establish the curriculum of preschool education. Official Bulletin of the State.No.32, 06/02/2006. 5042-5048.

Ministerio de Educación. Real Decreto 1333/1991, September 6, to establish the curriculum of preschool education. Official Bulletin of the State. No.216,09/09/1991.

Ministerio de Educación. Real Decreto 1630/2006, December 29, to establish the minimum curriculum of the second cycle of preschool education. Official Bulletin of the State. No. 4, 04/01/2007 . 480-481, 481.

Ministerio de Educación. Teaching of the Educational System. Available from http://www. educacion.gob.es/educacion/sistema-educativo/ensenanzas.html 11-6-2011, accessed 11 November, 2010.

Muñoz, C. (2006). Age and Rate of Foreign Language Learning. Clevedon: Multilingual Matters.

Schwab, J. (1978). The Practical: A Language for Curriculum, in J. Schwab, L. Wesbury \& N. Wilkof (eds.), Science, Curriculum and Liberal Education (Selected Essays). Chicago: The University of Chicago Press, 287.

Wang, C.D. (2007). Study of the Influence on the Children's Psychological Development Based on Sex of the Preschool Teachers, in Science \& Technology Information, 23: 208. 